\title{
PENGARUH SISTEM PENGENDALIAN INTERNAL TERHADAP KUALITAS LAPORAN KEUANGAN PEMERINTAH DAERAH \\ (STUDI KASUS PADA KANTOR DINAS PEKERJAAN UMUM DAN PENATAAN RUANG KABUPATEN MAMASA)
}

\author{
Carolus Askikarno P \\ Fakultas Ekonomi dan Bisnis \\ Universitas Kristen Indonesia Paulus Makassar \\ carolus@ukipaulus.ac.id
}

\begin{abstract}
Internal Control System Towards Quality of Municipal Financial Statement (Case Study at Kantor Dinas Pekerjaan Umum dan Penataan Ruang Mamasa Regency).

The purpose of this research is to determine the effect of the internal control system on the quality of local government financial reports on Dinas Pekerjaan Umum dan Penataan Ruang Kabupaten Mamasa. Data collection techniques using questionnaires. The sample in this research were 32 employee of Dinas Pekerjaan Umum dan Penataan Ruang Kabupaten Mamasa. This study uses simple random sampling technique. Data were analysed using regression analysis techniques, $f$-test, and t-test by software SPSS for windows. The results found that there was a significant influence between the control environment, risk assessment, control activities, information and communication, and monitoring of the quality of financial statements simultaneously; partially, and there is a significant influence between the control environment, risk assessment, control activities, information and communication, and monitoring of the quality of financial statements.
\end{abstract}

Keywords: control environment, risk assessment, control activities, information and communication, quality of financial statements

\section{PENDAHULUAN}

Laporan keuangan merupakan media bagi sebuah entitas dalam hal ini pemerintah untuk mempertanggung jawabkan kinerja keuangannya kepada publik. Pemerintah harus mampu menyajikan laporan keuangan yang mengandung informasi keuangan yang berkualitas. Dalam Standar Akuntansi Pemerintahan (SAP). Undang-Undang Nomor 71 Tahun 2010 tentang SAP dijelaskan bahwa laporan keuangan berkualitas itu memenuhi karakteristik, relevan, andal, dapat dibandingkan dan dapat dipahami.

Apabila informasi yang terdapat di dalam Laporan Keuangan Pemerintah Daerah memenuhi kriteria karakteristik laporan keuangan pemerintah seperti yang di syaratkan dalam Peraturan Pemerintah Nomor 71 Tahun 2010, berarti pemerintah daerah mampu mewujudkan transparansi dan akuntabilitas dalam pengelolaan keuangan daerah. Informasi yang terkandung dalam laporan keuangan yang dihasilkan oleh pemerintah daerah harus sesuai dengan kriterian nilai informasi yang di syaratkan oleh peraturan perundangundangan. Apabila tak sesuai dengan perundang-undangan, maka akan mengakibatkan kerugian daerah, potensi kekurangan daerah, kekurangan penerimaan, kelemahan administrasi, ketidak hematan, ketidak efesienan, ketidak efektifan (Sukmaningrum, 2009).

Sistem pengendalian internal pada pemerintah juga sangat diperlukan guna mendapatkan pengelolaan keuangan daerah yang efektif dan efesien. Sistem pengendalian 
internal menurut peraturan pemerintah Nomor 60 tahun 2008 yang mengatur Sistem Pengendlian Internal Pemerintah (SPIP) adalah 3 proses yang integral pada kegiatan dan tindakan yang dilakukan secara terus menerus oleh pimpinan dan tercapainya tujuan. Organisasi melaluai kegiatan yang efektif dan efesien, keandalan laporan keuangan, pengamanan aset Negara dan ketaatan terhadap peraturan perundang-undangan. Sistem pengendalian internal yang baik dalam suatu pemerintahan akan mampu menciptakan keseluruhan proses kegiatan yang baik pula, sehingga akan memeberikan keyakinan yang memadai bagi terciptanya pengamanan aset Negara dan keandalan laporan keuangan pemerintah daerah, dalam hal tersebut akan memberikan dampak positif bagi pengelolaan keuangan daerah. (Zalni, 2013). Selain itu penerapan sistem pengendalian internal dapat mencegah adanya suatu kegiatan yang tidak sesuai dengan ketentuan yang berlaku. Sehingga dapat memperoleh efisiensi, efektifitas, dan dapat mencegah kerugian Negara (Udiyanti, Atmadja, \& Darmawan, 2014).

Kualitas Laporan Pemerintah Daerah (LKPD) dapat tercermin dari hasil pemeriksaaan BPK. Pemeriksaan atas laporan keuangan dilakukan dalam rangka memberikan pendapat/opini atas kewajaran informasi keuangan yang disajikan dalam laporan keuangan. Adapun kriteria pemberian opini menurut Undang-Undang Nomor 15 Tahun 2004 tentang pemeriksaan, pengelolaan dan tanggungjawab keuangan negara mengenai kewajaran informasi keuangan yang disajikan dalam laporan keuangan yang didasarkan pada kriteria (a) kesesuaian dengan standar akuntansi pemerintahan, (b) kecukupan pengungkapan (adequate disclosures), (c) kepatuhan terhadap peraturan perundang-undangan, dan (d) efektifitas sistem pengendalian internal.

Implementasi sistem pengendalian intern menuntut adanya komitmen dan peran aktif para pimpinan daerah pada setiap level dan tingkatan organisasi, mengingat pemimpin daerah mempunyai peran yang sangat penting dalam upaya meningkatkan kinerja penyelenggaraan pemerintahan daerah. Peran kepemimpinan daerah pada dasarnya ada di semua tingkatan organisasi yang bersifat sistemik dan institusional. Sistemik artinya terkait dengan banyak orang yang bekerja berdasarkan suatu sistem dan pada suatu tingkatan tertentu dalam hierarkhi organisasional. Sedangkan institusional artinya melibatkan banyak orang dalam kepemimpinan tersebut dan masing-masing memiliki posisi dalam institusi tersebut. Oleh karena itu kepemimpinan daerah mempunyai keterkaitan yang sangat erat dalam usaha mencapai kinerja daerah. Sehingga pemimpin daerah haruslah memiliki kemampuan untuk menciptakan suatu kerja sama di antara sistem yang ada dalam pemerintahan daerah.

Pemerintah daerah berkewajiban mempublikasikan informasi berdasarkan laporan keuangan sebagai dasar pengambil keputusan. Dengan demikian, informasi yang dipublikasikan tersebut dapat dimanfaatkan oleh para pemakai. Informasi akan bermanfaat apabila informasi tersebut dapat dipahami, dipercaya dan digunakan oleh pemakai informasi tersebut (Andriani, 2010).

Ada empat opini yang biasa diberikan oleh BPK kepada entitas yakni opini Wajar Tanpa Pengecualian (WTP), opini Wajar Dengan Pengecualian (WDP), opini Tidak Memberikan Pendapat (TMP), dan opini Tidak Wajar (TM). Laporan hasil pemeriksaan (LHP) atas LKPD Tahun 2015 yang diserahkan oleh BPK Perwakilan Provinsi Sulawesi Barat menyatakan bahwa Pemerintah Daerah kota Mamasa mendapat predikat opini Wajar Tanpa Pengecualian (WTP). (www.mamuju.bpk.go.id dikutup 24 Oktober 2017). Dengan adanya opini tersebut, apakah laporan keuangan yang terbitkan juga menunjukkan adanya kualitas yang baik sehingga dapat dipergunakan dengan banyak tujuan dari pengguna yang berbeda. Namun berdasarkan berita yang dimuat dalam Makassar.tribunnews.com (2017) yang mengungkapkan masih ada dugaan korupsi proyek penanggulangan bencana di Kabupaten Mamasa. Hal ini mengidentifikasikan bahwa harus ada pengawasan internal yang lebih baik lagi sehingga tidak ada lagi dugaan yang muncul dalam masyarakat.

Berdasarkan uraian latar belakang peneliti bermaksud melalukan penelitian dengan judul: "Pengaruh Sistem Pengendalian Internal Terhadap Kualitas Laporan Keuangan Pemerintah Daerah (Studi Kasus Pada Kantor Dinas Pekerjaan Umum Dan Penataan Ruang Kab. Mamasa). Adapun maksud dan tujuan penelitian ini yaitu untuk mengetahui 
pengaruh Sistem Pengendalian internal terhadap Kualitas Laporan Keuangan Pemerintah Daerah. Dari hasil penelitian yang dilakukan diharapkan dapat memberikan sumbangan saran serta bahan pertimbangan dalam menentukan kebijakan khususnya yang berkaitan dengan sistem pengendalian internal terhadap kualitas laporan keungan daerah.

\section{KAJIAN LITERATUR}

\section{Sistem Pengendalian Internal}

Sistem pengendalian intern merupakan suatu perencanaan yang meliputi struktur organisasi dan semua metode dan alat-alat yang dikoordinasikan yang digunakan di dalam perusahaan dengan tujuan untuk menjaga keamanan harta milik perusahaan, memeriksa ketelitian dan kebenaran data akuntansi, mendorong efisiensi, dan membantu mendorong dipatuhinya kebijakan manajemen yang telah ditetapkan (Raharjo, 2013).

Sistem Pengendalian Internal adalah proses yang integral pada tindakan dan kegiatan yang dilakukan secara terus menerus oleh pimpinan dan seluru pegawai untuk memberikan keyakinan memadai atas tercapainya tujuan organisasi melalui kegiatan yang efektif dan efisien, keandalan pelaporan keuangan, pengamatan asset negara dan ketaatan terhadap peraturan perundang-undangan. Dalam rangka pencapaian visi, misi, dan tujuan serta pertangung jawaban kegiatan Instansi pemerintah wajib menerapkan setiap unsur dari Sistem Pengendalian Internal. Untuk memastikan bahwa Sistem Pengedalian Intern (SPI) tersebut sudah dirancang dan diimplementasikan dengan baik, dan secara memadai diperbaharui untuk memenuhi keadaan yang terus berubah perlu dilakukan pemantauan secara terus-menerus. Pimpinan Instansi Pemerintah melakukan pemantauan antara lain melalui evaluasi terpisah atas Sistem Pengendalian Internnya masing-masing untuk mengetahui kinerja dan efektifitas Sistem Pengendalian Intern serta cara meningkatkannya. Pemantauan juga berguna untuk mengidentifikasi dan mengatasi resiko utama seperti penggelapan, pemborosan, penyalagunaan, dan salah-kelola.

Pengendalian intern sebagai suatu proses yang dijalankan oleh dewan komisaris, manajemen dan personil lain entitas yang didisain untuk memberikan keyakinan yang memadai tentang pencapaian tiga golongan tujuan: (a) efektivitas dan efisiensi operasi (b) keandalan laporan keuangan dan (c) kepatuhan terhadap hukum dan peraturan yang berlaku.

\section{Tujuan Pengendalian Internal}

Arens et. Al. (2011) yang dialih bahasakan oleh Herman Wibowo memaparkan tiga tujuan umum manajemen dalam merancang sistem pengendalian internal yang efektif, yaitu:

1) Reliability Of Financial Reporting.

2) Efficiency and Effectiveness Of Operations

3) Complience With Laws and Regulations

Manajemen bertanggung jawab untuk menyiapkan laporan bagi para investor, kreditor dan pemakai lainnya. Manajemen memikul baik tanggung jawab hukum maupun professional untuk memastikan bahwa informasi telah disajikan secara wajar sesuai dengan persyaratan pelaporan seperti prinsip-prinsip akuntansi yang berlaku umum. Tujuan pengendalian internal yang efektif atas pelaporan keuangan adalah memenuhi tanggung jawab pelaporan keuangan tersebut.

Pengendalian dalam perusahaan akan mendorong pemakaian sumber daya secara efektif dan efisien untuk mengoptimalkan sasaran-sasaran perusahaan. Tujuan yang penting dari pengendalian ini adalah memperoleh informasi keuangan dan non-keuangan yang akurat tentang operasi perusahaan untuk keperluan pengambilan keputusan. Manajemen harus menguji efektifitas pelaksanaan pengendalian.

Tujuan penggunaan ini adalah untuk menentukan apakah pengendalian telah berjalan seperti yang telah dirancang dan apakah orang yang melaksanakan memiliki kewenangan serta kualifikasi yang diperlukan untuk melaksanakan pengendalian secara efektif. 


\section{Unsur-Unsur Sistem Pengendalian Internal}

Peraturan Pemerintah Nomor 60 Tahun 2008 tentang Sistem Pengendalian Internal Pemerintah meyebutkan bahwa SPIP terdiri dari unsur-unsur berikut :

1) Lingkungan pengendalian

2) Penilaian risiko

3) Kegiatan pengendalian

4) Informasi dan komunikasi

5) Pemantauan pengendalian intern

\section{Sistem Pengendalian Intern Pemerintah}

Dalam Peraturan Pemerintah Nomor 60 Tahun 2008 Tentang Sistem Pengendalian Intern Pemerintah menyebutkan bahwan sistem pengendalian intern pemerintah terdiri atas unsur sebagai berikut ;

a. Lingkungan Pengendalian, menetapkan corak suatu organisasi, mempengaruhi kesadaran orang-orangnya. Lingkungan pengendalian merupakan dasar untuk semua komponen pengendalian intern, menyediakan disiplin dan struktur.

b. Penaksiran Resiko adalah identifikasi dan analisis terhadap resiko yang relevan untuk mencapai tujuannya, membentuk suatu dasar untuk menentukan bagaimana resiko harus dikelola.

c. Aktivitas Pengendalian adalah kebijakan dan prosedur yang membantu menjamin bahwa arahan manajemen dilaksanakan.

d. Informasi dan Komunikasi adalah pengindentifikasian, penangkapan dan pertukaran informasi dalam suatu bentuk dan waktu yang memungkinkan orang melaksanakan tanggungjawab mereka.

e. Pemantauan adalah proses yang menentukan kualitas kinerja pengendalian intern sepanjang waktu.

\section{Laporan Keuangan Pemerintah}

Laporan keuangan merupakan bentuk pertanggungjawaban atas kepengurusan sumber daya ekonomi yang dimiliki oleh suatu entitas. Laporan keuangan yang diterbitkan harus disusun sesuai dengan standar akuntansi yang berlaku agar laporan keuangan tersebut dapat dibandingkan dengan laporan keuangan periode sebelumnya atau dibandingkan dengan laporan keuangan entitas yang lain.

Peraturan Menteri Dalam Negeri Nomor 13 Tahun 2006 tentang Pedoman Pengelolaan Keuangan Daerah, dalam ketentuan umumnya menyebutkan bahwa yang dimaksud dengan keuangan daerah adalah semua hak dan kewajiban daerah dalam rangka penyelenggaraan pemerintah daerah yang dapat dinilai dengan uang termasuk di dalamnya segala bentuk kekayaan yang berhubungan dengan hak dan kewajiban daerah tersebut. Selanjutnya dalam Pasal 4 dikatakan pula bahwa pengelolaan keuangan daerah dilakukan dengan tertib, taat pada peraturan perundang-undangan, efektif, efisien, ekonomis, transparan dan bertanggung jawab dengan memperhatikan asas keadilan, kepatuhan dan maanfaat untuk masyarakat.

Menurut Peraturan Pemerintah Nomor 71 Tahun 2010 pengertian laporan keuangan adalah sebagai berikut : "Laporan keuangan merupakan laporan yang terstruktur mengenai posisi keuangan dan transaksi-transaksi yang dilakukan oleh suatu entitas pelaporan."

Entitas pelaporan adalah unit pemerintahan yang terdiri dari satu atau lebih entitas akuntansi yang menurut ketentuan peraturan perundang-undangan wajib menyampaikan laporan pertanggungjawaban berupa laporan keuangan, yang terdiri dari :

1. Pemerintah pusat;

2. Pemerintah daerah

3. Satuan organisasi di lingkungan pemerintah pusat/daerah atau organisasi lainnya, jika menurut peraturan perundang-undangan satuan organisasi dimaksud wajib menyajikan laporan keuangan. 
Dari beberapa pengertian di atas dapat disimpulkan bahwa laporan keuangan adalah laporan tertulis yang memberikan informasi kuantitatif tentang posisi keuangan dari transaksi-transaksi yang dilakukan oleh suatu entitas pelaporan.

\section{Kualitas Laporan Keuangan}

Dalam memenuhi keinginan pemakai laporan, akuntansi keuangan perlu berupaya untuk membentuk dirinya agar lebih bermanfaat dan berdaya guna. Oleh karena itu perlu kriteria persyaratan laporan akuntansi keuangan yang dianggap dapat memenuhi keinginan tersebut yaitu keinginan para pemakai laporan keuangan (Harahap, 2008:145).

Karakteristik kualitatif laporan keuangan menurut Peraturan Pemerintah Nomor 71 Tahun 2010 tentang Standar Akuntansi Pemerintah (SAP) adalah sebagai berikut: "Karakteristik kualitatif laporan keuangan adalah ukuran-ukuran normatif yang perlu diwujudkan dalam informasi akuntansi sehingga dapat memenuhi tujuannya."

Keempat karakteristik berikut ini merupakan prasyarat normatif yang diperlukan agar laporan keuangan pemerintah dapat memenuhi kualitas yang dikehendaki :

1. Relevan

2. Andal

3. Dapat dibandingkan

4. Dapat dipahami

\section{Hubungan Sistem Pengendalian Intern dengan Kualitas Laporan Keuangan Pemerintah Daerah}

Tujuan sistem pengendalian internal menurut Warren et all (2005) salah satunya adalah untuk mengecek ketelitian dan keandalan data akuntansi. Dengan sistem akuntansi, risiko terjadinya kekeliruan dan kesalahan pencatatan atau perhitungan dapat diminimalisasi sehingga mengurangi kemungkinan pemerintah daerah mengalami kekeliruan. Suatu sistem yang berkualitas, dirancang, dibangun dan dapat bekerja dengan baik apabila bagian-bagian yang terintegrasi dengan sistem tersebut beroperasi sesuai dengan tugas dan tanggung jawabnya masing-masing. Salah satu bagian di dalam sistem informasi akuntansi yang menunjang kelancaran kerja sistem informasi akuntansi tersebut adalah pengendalian internal (internal control).

Wawan Sukmana dan Lia Anggarsari (2009) melakukan penelitian dengan Judul penelitian "Pengaruh Pengawasan Intern dan Pelaksanaan Sistem Akuntansi Keuangan Daerah Terhadap Kinerja Pemerintah Daerah" (Survey pada Organisasi Perangkat Daerah Kota Tasikmalaya). Dari hasil penelitian menyatakan bahwa nilai yang diperoleh dari perhitungan terhadap tanggapan responden mengenai Pengawasan Intern pada Dinas Kota Tasikmalaya Pengawasan Intern yang dilakukan atasan langsung terhadap bawahan telah dilakukan dengan baik pada Dinas Kota Tasikmalaya, atau dengan kata lain Dinas Kota Tasikmalaya telah melakukan Pengawasan Intern dengan baik.

\section{Skema Kerangka Pemikiran}

\section{Sistem Pengendalian}

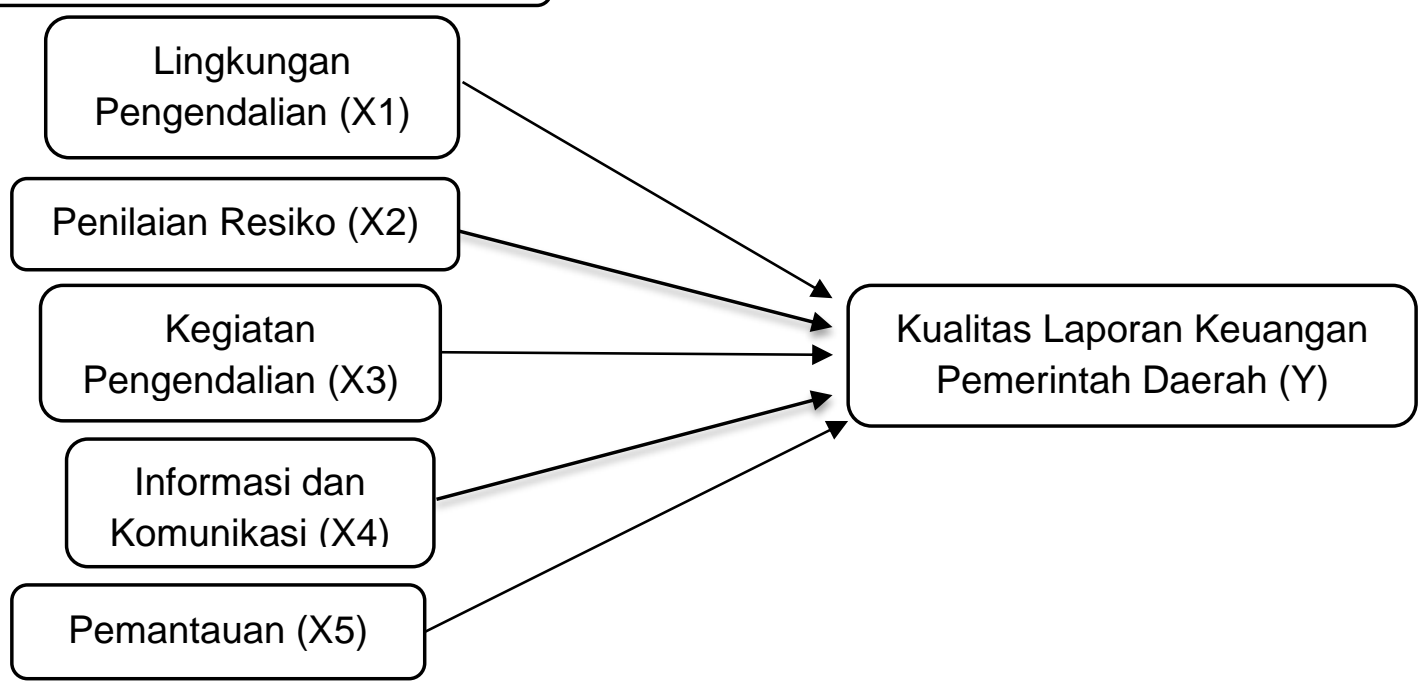




\section{METODE}

\section{Jenis Penelitian}

Penelitian ini dilakukan dengan menggunakan pendekatan kuantitatif. Metode penelitian kuantitatif merupakan metode penelitian yang berlandaskan pada filsafat, digunakan untuk meneliti pada populasi atau sampel tertentu, pengumpulan data menggunakan instrumen penelitian, analisis data bersifat kuantitatif atau statistik, dengan tujuan menguji hipotesis yang telah ditetapkan (Sugiyono, 2010).

\section{Populasi dan Sampel}

Populasi yang digunakan dalam penelitian ini yaitu pegawai Dinas Pekerjaan Umum dan Penataan Ruang Kabupaten Mamasa. Sampel yang diambil dari populasi harus betulbetul representatif (mewakili). Teknik pengambilan sampel yang digunakan adalah sampling Purposive, artinya penentuan sampel dengan pertimbangan tertentu. Adapun pertimbangan pemilihan sampel tersebut memiliki beberapa kriteria. Adapun kriterianya sebagai berikut :

1) Responden dalam penelitian ini adalah Para pegawai/staf yang berkaitan dengan bidang keuangan dan para pegawai/staff pemegang kas baik bendahara penerimaan maupun bendahara pengeluaran pada Kantor Pekerjaan Umum dan Penaan Ruang Kabupaten Mamasa.

2) Responden dalam penelitian ini adalah kepala sub bagian keuangan dan kepala dinas pekerjaan umum dan penataan ruang Kabupaten Mamasa selaku pengambil keputusan dalam mengunakan anggaran dan menggunakan barang.

\section{Metode Pengumpulan Data}

Data yang digunakan adalah data primer. Dimana data primer merupakan sumber data penelitian yang diperoleh secara langsung dari sumber asli (tidak melalui media perantara). Indriantoro \& Supomo (2002). Metode pengumpulan data yang digunakan adalah dengan mendatangi secara langsung kantor Dinas Pekerjaan Umum dan Penataan Ruang Kab Mamasa dan memberikan kuesioner yang berisi pertanyaan terstruktur yang ditujukan kepada responden. Dalam pengumpulan data, peneliti menunggu responden menjawab semua kuesioner yang telah disediakan sebelumnya. Untuk dapat menyelesaikan penyebaran kuesioner tersebut, peneliti memperkirakan waktu selama 2 minggu.

\section{Definisi Operasional Variabel \\ Variabel Independen \\ Sistem Pengendalian Intern}

Pengendalian intern adalah suatu proses untuk memberikan arahan dan pengawasan serta memberikan keyakinan dan jaminan yang memadai atas tercapainya tujuan organisasi secara efektif dan efisien serta ketaatan terhadap peraturan perundangundangan.

Dalam instrumen ini pengukuran menggunakan skala Likert dengan skor 1 sampai 5. Skala 1 TP (Tidak Pernah), artinya sistem pengendalian intern pemerintah sangat rendah. Skala 2 JS (Jarang Sekali), artinya sistem pengendalian intern pemerintah rendah. Skala 3 KK (Kadang-Kadang), artinya sistem pengendalian intern pemerintah telah cukup. Skala $4 \mathrm{~S}$ (Sering), artinya sistem pengendalian intern pemerintah tinggi. Skala 5 SS (Sangat Sering), artinya sistem pengendalian intern pemerintah sangat tinggi.

\section{Lingkungan Pengendalian (X1)}

Lingkungan pengendalian menggambarkan keseluruhan sikap organisasi yang memengaruhi kesadaran dan tindakan personel organisasi mengenai pengendalian. Berbagai faktor yang membentuk lingkungan pengendalian dalam suatu entitas (Indra, 2011:11).

\section{Penilaian Risiko (X2)}

Penilaian risiko untuk tujuan pelaporan keuangan adalah proses identifikasi, analisis, dan pengelolaan resiko entitas yang berkaitan dengan penyusunan laporan keuangan sesuai dengan prinsip akuntansi yang berlaku umum. Diawali dengan penetapan maksud 
dan tujuan instansi Pemerintah yang jelas dan konsisten baik pada tingkat kegiatan. Selanjutnya Instansi Pemerintah mengidentifikasi secara efisien dan efektif risiko yang dapat menghambat pencapian tujuan tersebut, baik yang bersumber dari dalam maupun luar instansi (Indra, 2011:12).

\section{Kegiatan Pengendalian (X3)}

Aktivitas pengendalian adalah kebijakan dan prosedur yang dibuat untuk memastikan pelaksanaan petunjuk yang dibuat oleh manajemen. kebijakan dan prosedur yang dibangun oleh manajemen untuk mencapai tujuan laporan keuangan yang obyektif (Indra, 2011:12).

\section{Informasi dan Komunikasi (X4)}

Kebijakan dan prosedur pengendalian yang berkaitan dengan sistem akuntansi adalah bahwa transaksi dilaksanakandengan mencegah terjadinya salah saji potensial terhadap pernyataan manajemen dalam laporan keuangan (Indra, 2011:12). Instansi pemerintah harus memiliki informasi yang relevan dan dapat diandalkan baik informasi keuangan maupun non keuangan, yang berhubungan dengan peristiwaperistiwa eksternal dan internal, yang menyediakan dan memanfaatkan berbagai bentuk dan sarana komunikasi serta mengelola, mengembangkan dan memperbarui sistem informasi secara terus menerus.

\section{Pemantauan (X5)}

Proses penilaian kualitas kinerja dari struktur pengendalian internal sepanjang waktu (Indra, 2011:13). Dilaksanakan melalui pemantauan berkelanjutan, evaluasi terpisah, dan tindak lanjut rekomendasi hasil audit dan review lainnya. Pemantauan berkelanjutan diselenggarakan melalui kegiatan pengelolaan rutin, supervisi, pembandingan, rekonsiliasi, dan tindakan lain yang terkait dalam pelaksanakan tugas.

\section{Variabel Dependen}

\section{Kualitas Laporan Keuangan Pemerintah Daerah (Y)}

Kualitas Laporan Keuangan Pemerintah Daerah, yaitu kemampuan informasi yang disajikan dalam laporan keuangan dapat dipahami, dan memenuhi kebutuhan pemakainya dalam pengambilan keputusan, bebas dari pengertian yang menyesatkan, kesalahan material serta dapat diandalkan, sehingga laporan keuangan tersebut dapat dibandingkan dengan periode-periode sebelumnya. Dalam instrumen ini pengukuran menggunakan skala Likert dengan skor 1 sampai 5. Skala 1 TP (Tidak Pernah), artinya kualitas laporan keuangan sangat rendah. Skala 2 JS (Jarang Sekali), artinya kualitas laporan keuangan rendah. Skala 3 KK (Kadang-Kadang), artinya kualitas laporan keuangan telah cukup. Skala 4 S (Sering), artinya kualitas laporan keuangan baik. Skala 5 SS (Sangat Sering), artinya kualitas laporan keuangan sangat baik.

\section{Metode Analisis Data Uji Kualitas Data}

Sebelum menggunakan instrument terlebih dahulu dilakukan uji coba untuk mendapatkan bukti pernyataan yang valid dan handal, maka dilakukan uji validasi dan uji reliabilitas.

\section{Uji Asumsi Klasik}

Sebelum melakukan analisis regresi linier berganda, terdapat beberapa uji asumsi klasik yang terlebih dahulu harus dipenuhi. Uji asumsi klasik dalam penelitian ini terdiri dari uji normalitas data, uji multikolinieritas, dan uji heteroskedastisitas.

\section{Alat Analisis Data}

Alat analisis data yang digunakan untuk menguji hipotesis yang dirumuskan adalah analisis regresi berganda dengan bantuan Software SPSS (Statistical Package For Social Science). Analisis regresi berganda menunjukkan pengaruh hubungan antara variabel independen terhadap variabel dependen dengan persamaan sebagai berikut :

$$
\begin{aligned}
\mathbf{Y}=\boldsymbol{\alpha}+ & \boldsymbol{\beta} \mathbf{1 X} \mathbf{1}+\boldsymbol{\beta} \mathbf{2 X} \mathbf{2}+\boldsymbol{\beta} \mathbf{3 X} \mathbf{3}+\boldsymbol{\beta} \mathbf{X X} \mathbf{4}+\boldsymbol{\beta} \mathbf{5 X 5}+\mathbf{e} \ldots . . \\
& \text { Keterangan : } \\
& \mathrm{Y}=\text { Kualitas Laporan Keuangan Pemerintah Daerah }
\end{aligned}
$$


$\alpha=$ Konstanta

$\beta 1, \beta 2, \beta 3=$ koefisien korelasi

$\mathrm{X} 1$ = Lingkungan Pengendalian

X2 = Penilaian Resiko

X3 $=$ Kegiatan Pengendalian

X4 = Informasi \& Komunikasi

$\mathrm{X} 5=$ Pemantauan

$\mathrm{e}=$ variabel lain yang mempengaruhi

\section{Pengujian Hipotesis}

\section{Uji Koefisien Determinasi (R2)}

Koefisien determinasi (R2) mengukur seberapa besar kemampuan model dalam menerangkan variasi variabel dependen. Nilai R2 adalah diantara nol dan satu. Nilai R2 yang kecil menunjukkan kemampuan variabel independen dalam menjelaskan variasi variabel dependen amat terbatas.

\section{Uji Simultan (Ftest)}

Uji statistik F pada dasarnya menunjukkan apakah semua variabel independen yang dimasukan dalam model mempunyai pengaruh secara bersama-sama atau simultan terhadap variabel dependen (Ghozali, 2011). Dengan tingkat signifikan sebesar 5\% $(\alpha=$ $0,05)$.

\section{Uji Statistik t (t-test)}

Pengujian hipotesis dilakukan dengan uji regresi secara parsial (uji $t$ ). Uji statistik $t$ pada dasarnya untuk mengetahui pengaruh variabel independen secara individual dalam menerangkan variabel dependen secara signifikan. Jika probabilitas sig. < 0,05 maka variabel independen secara individual mempengaruhi variabel dependen (Ghozali, 2011).

\section{HASIL DAN PEMBAHASAN}

\section{Deskripsi Variabel Independen Lingkungan Pengendalian (X1)}

Tabel 1

Tanggapan Responden Mengenai Lingkungan Pengendalian

\begin{tabular}{|c|c|c|c|c|c|c|c|c|c|c|c|}
\hline \multirow{3}{*}{ KETERANGAN } & \multicolumn{10}{|c|}{ Skor } & \multirow{3}{*}{ Jumlah } \\
\hline & \multicolumn{2}{|c|}{$\begin{array}{c}\text { SS } \\
5 \\
\end{array}$} & \multicolumn{2}{|c|}{$\begin{array}{l}S \\
4 \\
\end{array}$} & \multicolumn{2}{|c|}{$\begin{array}{c}\text { RR } \\
3 \\
\end{array}$} & \multicolumn{2}{|c|}{$\begin{array}{c}\text { TS } \\
2 \\
\end{array}$} & \multicolumn{2}{|c|}{$\begin{array}{c}\text { STS } \\
1 \\
\end{array}$} & \\
\hline & $\mathbf{F}$ & $\%$ & $\mathbf{F}$ & $\%$ & $\mathbf{F}$ & $\%$ & $\mathbf{F}$ & $\%$ & $\mathbf{F}$ & $\%$ & \\
\hline Pertanyaan 1 & 10 & 10 & 19 & 19 & 2 & 2 & 0 & 0 & 1 & 1 & 133 \\
\hline Pertanyaan 2 & 10 & 10 & 17 & 17 & 4 & 4 & 1 & 1 & 0 & 0 & 132 \\
\hline Pertanyaan 3 & 15 & 15 & 14 & 14 & 3 & 3 & 0 & 0 & 0 & 0 & 140 \\
\hline Pertanyaan 4 & 11 & 11 & 19 & 19 & 2 & 2 & 0 & 0 & 0 & 0 & 137 \\
\hline Pertanyaan 5 & 11 & 11 & 18 & 18 & 3 & 3 & 0 & 0 & 0 & 0 & 136 \\
\hline Pertanyaan 6 & 12 & 12 & 18 & 18 & 2 & 2 & 0 & 0 & 0 & 0 & 138 \\
\hline Pertanyaan 7 & 11 & 11 & 18 & 18 & 2 & 2 & 1 & 1 & 0 & 0 & 135 \\
\hline Pertanyaan 8 & 6 & 6 & 20 & 20 & 5 & 5 & 1 & 1 & 0 & 0 & 127 \\
\hline
\end{tabular}

Sumber : Data primer diolah tahun 2019

Kesimpulan dari hasil penelitian ini menunjukkan bahwa responden melihat pada kepemimpinan yang kondusif pada kantor tempat bekerja saat ini yang dapat ditunjukkan dengan nilai jumlah indikator yang diperoleh paling tinggi pada variabel lingkungan pengendalian yaitu 140 . 
Tabel 2

Tanggapan Responden Mengenai Penilaian Risiko

\begin{tabular}{|c|c|c|c|c|c|c|c|c|c|c|c|}
\hline \multirow{3}{*}{ Keterangan } & \multicolumn{10}{|c|}{ Skor } & \multirow{3}{*}{ Jumlah } \\
\hline & \multicolumn{2}{|c|}{$\begin{array}{c}\text { SS } \\
5\end{array}$} & \multicolumn{2}{|c|}{$\begin{array}{l}S \\
4\end{array}$} & \multicolumn{2}{|c|}{$\begin{array}{c}\text { RR } \\
3\end{array}$} & \multicolumn{2}{|c|}{$\begin{array}{c}\text { TS } \\
2\end{array}$} & \multicolumn{2}{|c|}{$\begin{array}{c}\text { STS } \\
1\end{array}$} & \\
\hline & $\mathbf{F}$ & $\%$ & $\mathbf{F}$ & $\%$ & $\mathbf{F}$ & $\%$ & $\mathbf{F}$ & $\%$ & $\mathbf{F}$ & $\%$ & \\
\hline Pertanyaan 1 & 11 & 11 & 20 & 20 & 1 & 1 & 0 & 0 & 0 & 0 & 138 \\
\hline Pertanyaan 2 & 13 & 13 & 18 & 18 & 1 & 1 & 0 & 0 & 0 & 0 & 140 \\
\hline Pertanyaan 3 & 6 & 6 & 16 & 16 & 8 & 8 & 2 & 2 & 0 & 0 & 122 \\
\hline Pertanyaan 4 & 4 & 4 & 20 & 20 & 6 & 6 & 2 & 2 & 0 & 0 & 122 \\
\hline Pertanyaan 5 & 3 & 3 & 15 & 15 & 9 & 9 & 3 & 3 & 2 & 2 & 110 \\
\hline
\end{tabular}

Kesimpulan dari hasil penelitian ini menunjukkan bahwa responden melihat pada penerapan tujuan yang jelas pada tingkat kegiatan yang dapat ditunjukkan dengan nilai jumlah indikator yang diperoleh paling tinggi pada penilaian risiko yaitu 140.

\section{Kegiatan Pengendalian (X3)}

Tabel 3

Tanggapan Responden Mengenai Kegiatan Pengendalian

\begin{tabular}{|c|c|c|c|c|c|c|c|c|c|c|c|}
\hline \multirow{3}{*}{ Keterangan } & \multicolumn{10}{|c|}{ Skor } & \multirow{3}{*}{ Jumlah } \\
\hline & \multicolumn{2}{|c|}{$\begin{array}{c}\text { SS } \\
5\end{array}$} & \multicolumn{2}{|c|}{$\begin{array}{l}S \\
4\end{array}$} & \multicolumn{2}{|c|}{$\begin{array}{c}\mathbf{R R} \\
3\end{array}$} & \multicolumn{2}{|c|}{$\begin{array}{c}\text { TS } \\
2\end{array}$} & \multicolumn{2}{|c|}{$\begin{array}{c}\text { STS } \\
1\end{array}$} & \\
\hline & $\mathbf{F}$ & $\%$ & $\mathbf{F}$ & $\%$ & $\bar{F}$ & $\%$ & $\mathbf{F}$ & $\%$ & $\bar{F}$ & $\%$ & \\
\hline Pertanyaan 1 & 7 & 7 & 22 & 22 & 0 & 0 & 3 & 3 & 0 & 0 & 129 \\
\hline Pertanyaan 2 & 10 & 10 & 18 & 18 & 2 & 2 & 2 & 2 & 0 & 0 & 132 \\
\hline Pertanyaan 3 & 8 & 8 & 20 & 20 & 4 & 4 & 0 & 0 & 0 & 0 & 132 \\
\hline Pertanyaan 4 & 13 & 13 & 15 & 15 & 3 & 3 & 1 & 1 & 0 & 0 & 136 \\
\hline Pertanyaan 5 & 9 & 9 & 18 & 18 & 4 & 4 & 1 & $\overline{1}$ & 0 & 0 & 131 \\
\hline Pertanyaan 6 & 7 & 7 & 18 & 18 & 5 & 5 & 1 & 1 & 0 & 0 & 124 \\
\hline Pertanyaan 7 & 3 & 3 & 18 & 18 & 10 & 10 & 1 & 1 & 0 & 0 & 119 \\
\hline Pertanyaan 8 & 6 & 6 & 19 & 19 & 7 & 7 & 0 & 0 & 0 & 0 & 127 \\
\hline Pertanyaan 9 & 8 & 8 & 16 & 16 & 7 & 7 & 1 & 1 & 0 & 0 & 127 \\
\hline Pertanyaan 10 & 4 & 4 & 12 & 12 & 14 & 14 & 2 & 2 & 0 & 0 & 114 \\
\hline Pertanyaan 11 & 10 & 10 & 20 & 20 & 2 & 2 & 0 & 0 & 0 & 0 & 136 \\
\hline
\end{tabular}

Kesimpulan dari hasil penelitian ini menunjukkan bahwa responden melihat pada dokumentasi yang baik atas sistem pengendalian intern serta transaksi dan kejadian penting yang dapat ditunjukkan dengan nilai jumlah indikator yang diperoleh paling tinggi pada kegiatan pengendalian yaitu 136 .

\section{Dimensi Informasi dan Komunikasi (X4)}

Tabel 4

Tanggapan Responden Mengenai Dimensi Informasi dan Komunikasi

\begin{tabular}{|c|c|c|c|c|c|c|c|c|c|c|c|}
\hline \multirow{3}{*}{ Keterangan } & \multicolumn{10}{|c|}{ Skor } & \multirow{3}{*}{ Jumlah } \\
\hline & \multicolumn{2}{|c|}{$\begin{array}{c}\text { SS } \\
5\end{array}$} & \multicolumn{2}{|c|}{$\begin{array}{l}S \\
4 \\
\end{array}$} & \multicolumn{2}{|c|}{$\begin{array}{c}\text { RR } \\
\mathbf{3} \\
\end{array}$} & \multicolumn{2}{|c|}{$\begin{array}{c}\text { TS } \\
2 \\
\end{array}$} & \multicolumn{2}{|c|}{$\begin{array}{c}\text { STS } \\
1\end{array}$} & \\
\hline & $\mathbf{F}$ & $\%$ & $\mathbf{F}$ & $\%$ & $\bar{F}$ & $\%$ & $\mathbf{F}$ & $\%$ & $\bar{F}$ & $\%$ & \\
\hline Pertanyaan 1 & 15 & 15 & 14 & 14 & 3 & 3 & 0 & 0 & 0 & 0 & 140 \\
\hline Pertanyaan 2 & 13 & 13 & 18 & 18 & 1 & 1 & 0 & 0 & 0 & 0 & 140 \\
\hline Pertanyaan 3 & 8 & 8 & 15 & 15 & 9 & 9 & 0 & 0 & 0 & 0 & 127 \\
\hline
\end{tabular}

Kesimpulan dari hasil penelitian ini menunjukkan bahwa responden melihat pada informasi yang baik dan komunikasi yang baik yang dapat ditunjukkan dengan nilai jumlah indikator yang diperoleh paling tinggi pada dimensi informasi dan komunikasi yaitu 140 . 


\section{Dimensi Pemantauan (X5)}

Tabel 5

Tanggapan Responden Mengenai Dimensi Pemantauan

\begin{tabular}{|c|c|c|c|c|c|c|c|c|c|c|c|}
\hline \multirow{3}{*}{ Keterangan } & \multicolumn{10}{|c|}{ Skor } & \multirow{3}{*}{ Jumlah } \\
\hline & \multicolumn{2}{|c|}{$\begin{array}{c}\text { SS } \\
5\end{array}$} & \multicolumn{2}{|c|}{$\begin{array}{l}S \\
4\end{array}$} & \multicolumn{2}{|c|}{$\begin{array}{c}\text { RR } \\
3\end{array}$} & \multicolumn{2}{|c|}{$\begin{array}{c}\text { TS } \\
2\end{array}$} & \multicolumn{2}{|c|}{$\begin{array}{c}\text { STS } \\
1\end{array}$} & \\
\hline & $\mathbf{F}$ & $\%$ & $\mathbf{F}$ & $\%$ & $\mathbf{F}$ & $\%$ & $\mathbf{F}$ & $\%$ & $\mathbf{F}$ & $\%$ & \\
\hline Pertanyaan 1 & 9 & 9 & 20 & 20 & 2 & 2 & 1 & 1 & 0 & 0 & 133 \\
\hline Pertanyaan 2 & 7 & 7 & 20 & 20 & 12 & 12 & 2 & 2 & 0 & 0 & 12 \\
\hline Pertanyaan 3 & 11 & 11 & 16 & 16 & 4 & 4 & 1 & 1 & 0 & 0 & $\overline{13}$ \\
\hline
\end{tabular}

Kesimpulan dari hasil penelitian ini menunjukkan bahwa responden melihat pada pemantauan berkelanjutan dan penyelesaian audit yang dapat ditunjukkan dengan nilai jumlah indikator yang diperoleh paling tinggi pada dimensi pemantauan yaitu 133 .

\section{Deskripsi Variabel Dependen Kualitas Laporan Keuangan Pemerintah Daerah (Y) \\ Tabel 6}

Tanggapan Responen Mengenai Laporan Keuangan

\begin{tabular}{|c|c|c|c|c|c|c|c|c|c|c|c|}
\hline \multirow{3}{*}{ Keterangan } & \multicolumn{10}{|c|}{ Skor } & \multirow{3}{*}{ Jumlah } \\
\hline & \multicolumn{2}{|c|}{$\begin{array}{c}\text { SS } \\
5\end{array}$} & \multicolumn{2}{|c|}{$\begin{array}{l}S \\
4\end{array}$} & \multicolumn{2}{|c|}{$\begin{array}{c}\mathbf{R R} \\
\mathbf{3}\end{array}$} & \multicolumn{2}{|c|}{$\begin{array}{c}\text { TS } \\
2\end{array}$} & \multicolumn{2}{|c|}{$\begin{array}{c}\text { STS } \\
1\end{array}$} & \\
\hline & $\mathbf{F}$ & $\%$ & $\mathbf{F}$ & $\%$ & $\mathbf{F}$ & $\%$ & $\mathbf{F}$ & $\%$ & $\mathbf{F}$ & $\%$ & \\
\hline Pertanyaan 1 & 10 & 10 & 17 & 17 & 1 & 1 & 4 & 4 & 0 & 0 & 129 \\
\hline Pertanyaan 2 & 11 & 11 & 20 & 20 & 1 & 1 & 0 & 0 & 0 & 0 & 138 \\
\hline Pertanyaan 3 & 11 & 11 & 15 & 15 & 6 & 6 & 0 & 0 & 0 & 0 & 133 \\
\hline Pertanyaan 4 & 10 & 10 & 21 & 21 & 1 & 1 & 0 & 0 & 0 & 0 & 137 \\
\hline Pertanyaan 5 & 8 & 8 & 21 & 21 & 2 & 2 & 1 & 1 & 0 & 0 & 132 \\
\hline Pertanyaan 6 & 4 & 4 & 26 & 26 & 2 & 2 & 0 & 0 & 0 & 0 & 130 \\
\hline Pertanyaan 7 & 8 & 8 & 18 & 18 & 6 & 6 & 0 & 0 & 0 & 0 & 130 \\
\hline Pertanyaan 8 & 3 & 3 & 18 & 18 & 11 & 11 & 0 & 0 & 0 & 0 & 120 \\
\hline Pertanyaan 9 & 5 & 5 & 19 & 19 & 5 & 5 & 2 & 2 & 1 & 1 & 121 \\
\hline Pertanyaan 10 & 8 & 8 & 18 & 18 & 6 & 6 & 0 & 0 & 0 & 0 & 130 \\
\hline
\end{tabular}

\subsection{Uji Validitas dan Uji Reliabilitas}

\subsubsection{Uji Validitas}

Uji validitas digunakan untuk menguji sejauh mana ketepatan alat pengukur dapat mengungkapkan konsep gejala/kejadian yang diukur. Uji validitas digunakan untuk mengukur sah atau tidaknya suatu kuesioner, suatu kuesioner dikatakan valid jika Pernyataan pada kuesioner mampu untuk mengungkapkan sesuatu yang akan diukur oleh kuesioner tersebut. Uji validitas dihitung dengan membandingkan nilai $r$ hitung (correlated item-total correlation) dengan nilai $r$ tabel, jika $r$ hitung $>$ dari $r$ tabel (pada taraf signifikansi $5 \%$ ) maka Pernyataan tersebut dinyatakan valid. Hasil pengujian diperoleh sebagai berikut :

Tabel 7

Hasil Pengujian Validitas Item-Total Statistics

\begin{tabular}{|l|r|r|r|r|}
\hline & $\begin{array}{c}\text { Scale Mean if } \\
\text { Item Deleted }\end{array}$ & $\begin{array}{c}\text { Scale Variance if } \\
\text { Item Deleted }\end{array}$ & $\begin{array}{c}\text { Corrected Item- } \\
\text { Total Correlation }\end{array}$ & $\begin{array}{c}\text { Cronbach's Alpha if } \\
\text { Item Deleted }\end{array}$ \\
\hline P1 & 240.84 & 476.201 & .470 & .735 \\
P2 & 240.88 & 472.952 & .609 & .732 \\
P3 & 240.63 & 481.339 & .402 & .737 \\
P4 & 240.72 & 480.531 & .493 & .737 \\
P5 & 240.75 & 478.710 & .526 & .736 \\
P6 & 240.69 & 479.060 & .540 & .736 \\
P7 & 240.78 & 478.757 & .458 & .736 \\
P8 & 241.03 & 478.999 & .458 & .736 \\
P9 & 240.69 & 481.448 & .498 & .737 \\
P10 & 240.63 & 482.629 & .431 & .738 \\
P11 & 241.19 & 480.028 & .354 & .737
\end{tabular}




\begin{tabular}{|l|l|l|r|r|} 
P12 & 241.19 & 478.609 & .442 & .736 \\
P13 & 241.56 & 468.254 & .550 & .730 \\
P14 & 240.97 & 477.838 & .438 & .736 \\
P15 & 240.88 & 476.629 & .467 & .735 \\
P16 & 240.88 & 482.694 & .387 & .738 \\
P17 & 240.75 & 480.194 & .379 & .737 \\
P18 & 240.91 & 471.443 & .672 & .731 \\
P19 & 241.09 & 474.023 & .478 & .734 \\
P20 & 241.28 & 481.047 & .397 & .737 \\
P21 & 241.03 & 478.547 & .511 & .736 \\
P22 & 241.03 & 476.031 & .491 & .734 \\
P23 & 241.44 & 471.609 & .609 & .732 \\
P24 & 240.75 & 480.968 & .487 & .737 \\
P25 & 240.63 & 474.242 & .652 & .733 \\
P26 & 240.63 & 480.048 & .539 & .736 \\
P27 & 241.03 & 472.612 & .630 & .732 \\
P28 & 240.84 & 480.910 & .406 & .737 \\
P29 & 240.97 & 477.838 & .497 & .735 \\
P30 & 240.84 & 470.330 & .677 & .731 \\
TOTAL & 122.50 & 123.355 & 1.000 & .906 \\
\hline
\end{tabular}

Tabel menunjukkan bahwa semua indikator yang digunakan untuk mengukur variabelvariabel yang digunakan dalam penelitian ini mempunyai koefisien korelasi yang lebih besar dari $r$ tabel $=0,3494$ (nilai $r$ tabel untuk $n=32$ ). Sehingga semua indikator dari variabel penelitian ini adalah valid.

\section{Uji Reliabilitas}

Uji reliabilitas adalah alat untuk mengukur suatu kuesioner yang merupakan indikator dari variabel atau konstruk. Suatu kuesioner dikatakan reliabel atau handal jika jawaban seseorang terhadap pernyataan adalah konsisten atau stabil dari waktu ke waktu.

Pengujian reliabilitas dalam penelitian ini adalah dengan menggunakan rumus alpha. Hasil pengujian reliabilitas untuk masing-masing variabel diperoleh data sebagai berikut :

\section{Tabel 7}

Hasil Pengujian Reabilitas

Reliability Statistics

\begin{tabular}{|r|r|}
\hline Cronbach's Alpha & N of Items \\
\hline .743 & 31 \\
\hline
\end{tabular}

Sumber: Data primer diolah pada tahun 2019

Dalam penelitian ini, uji reliabilitas dilakukan dengan melihat hasil perhitungan nilai cronbach alpha ( $\alpha$ ). Suatu variabel dikatakan reliabel jika memberikan nilai cronbach alpha $(\alpha)>0,7$ yaitu bila dilakukan penelitian ulang dengan waktu dan variabel yang berbeda akan menghasilkan kesimpulan yang sama. Tetapi sebaliknya bila alpha $(\alpha)<0,7$ maka dianggap kurang handal, artinya bila variabel-variabel tersebut dilakukan penelitian ulang dengan waktu yang berbeda akan menghasilkan kesimpulan yang berbeda.

Hasil pengujian reliabilitas dalam tabel 7 menunjukkan bahwa semua variabel dalam penelitian mempunyai koefisien alpha $(\alpha)$ yang cukup besar yaitu $>0,70$ sehingga dapat dikatakan semua konsep pengukur masing-masing variabel dari kuesioner adalah reliabel yang berarti bahwa kuesioner yang digunakan dalam penelitian ini merupakan kuesioner yang handal.

\subsection{Pengujian Asumsi Klasik}

\subsubsection{Uji Normalitas}

Uji normalitas dilakukan untuk mengetahui apakah data yang digunakan memiliki distribusi normal. Pengujian normalitas dilakukan dengan menggunakan P-P Plot Test. Pengujian normalitas dapat dideteksi dengan melihat penyebaran data (titik) pada sumbu diagonal dari grafik distribusi normal, dan hasilnya dapat dilihat pada gambar 4 berikut: 


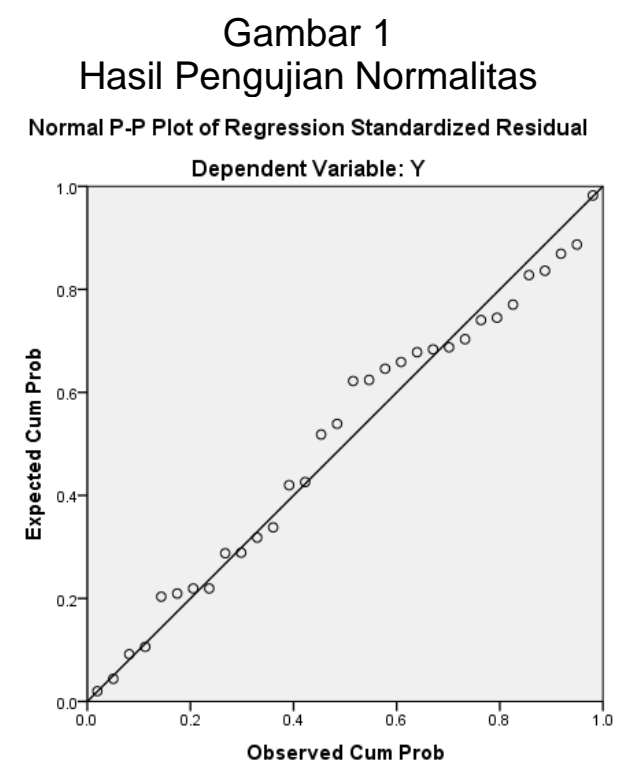

Berdasarkan P-P Plot di atas, terlihat bahwa titik-titik mengikuti dan mendekati garis diagonalnya sehingga dapat disimpulkan bahwa model regresi memenuhi asumsi normalitas data.

\subsubsection{Uji Multikolinieritas}

Uji multikolinieritas dilakukan dengan melihat tolerance value dan variance inflation factor (VIF), kriteria pengujian apabila terddapat variable bebas yang memeliki nilai tolerance value $>0,1$ dan nilai VIF $<10$, maka dapat disimpulkan bahwa tidak terjadi multikolonieritas dalam data sehingga asumsi nonmultikolinieritas terpenuhi. Berikut hasil uji multikolinieritas dengan menggunakan program SPSS 23.0 for windows.

Tabel 7

Hasil Pengujian Multikolinieritas

Coef ficients $^{a}$

\begin{tabular}{|c|c|c|}
\hline \multirow{2}{*}{ Model } & \multicolumn{2}{|c|}{ Collinearity Statistics } \\
\cline { 2 - 4 } & Tolerance & VIF \\
\hline \multirow{2}{*}{ (Constant) } & & \\
X1 & .357 & 2.799 \\
X2 & .624 & 1.602 \\
X3 & .361 & 2.771 \\
X4 & .548 & 1.825 \\
X5 & .452 & 2.210 \\
\hline \multicolumn{2}{|c|}{ a. Dependent Variable: Y } \\
\hline \multicolumn{2}{|c|}{}
\end{tabular}

Dari tabel output diatas, diketahui bahwa nilai tolerance kelima variabel bebas $(0,357)$, $(0,624),(0,361),(0,548),(0,452)>0,1$ dan nilai VIF dari kelima variabel tersebut $(2,799)$, $(1,602),(2,771),(1,825)$, dan $(2,210)<10$. Dengan demikian dapat disimpulkan bahwa tidak terjadi multikolinieritas dalam data ini.

\subsubsection{Uji Heteroskedastisitas}

Cara untuk mendeteksi adanya heteroskedastisitas yaitu dengan melihat grafik plot Antara nilai prediksi variabel terikat (ZPRED) dengan residualnya (SRESID). Deteksi ada tidaknya heteroskedastisitas dapat dilakukan dengan melihat ada tidaknya pola tertentu pada grafik scatteroplot antara ZPRED dan SRESID dimana sumbu $Y$ adalah $Y$ yang telah diprediksi, dan sumbu $X$ adalah residual ( $Y$ prediksi $-Y$ sesungguhnya). Denga dasar analisis sebagai berikut :

1. Jika ada pola tertentu, seperti titik-titik yang ada membentuk pola tertentu dan teratur (bergelombang, melebar kemudian menyempit), maka mengindikasikan terjadinya heteroskedastis.

2. Jika tidak ada pola yang jelas, serta titik-titik menyebar di atas dan di bawah angka 0 pada sumbu Y, maka tidak terjadi heteroskeda. 
Gambar 4.

Hasil Pengujian Heteroskedastisitas

Scatterplot

Dependent Variable: $Y$

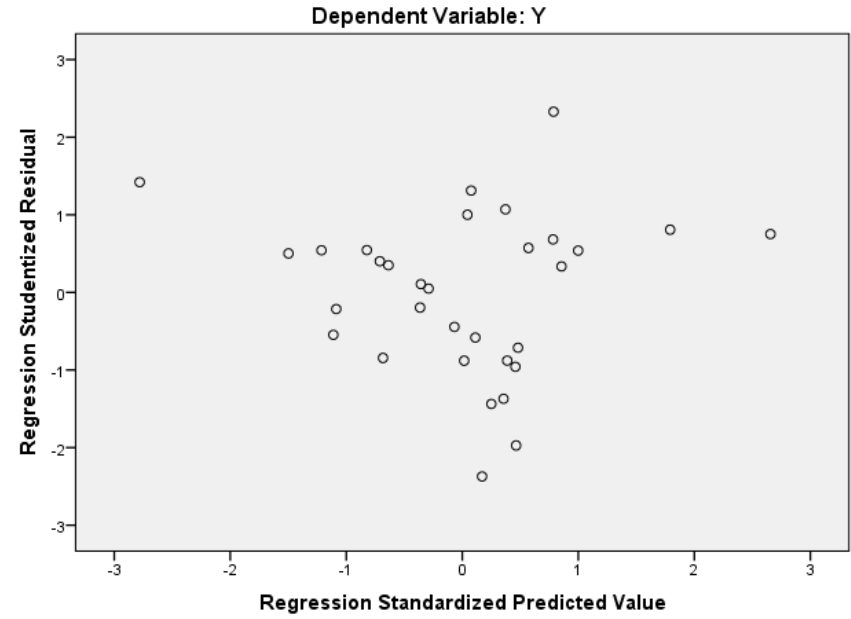

Berdasarkan scatterplot di atas, terlihat bahwa titik - titik koordinat menyebar tidak beraturan atau menyebar secara acak, yang menunjukkan tidak ditemukannya indikasi pelanggaran gejala heteroskedastisitas dalam data.

Dikarenakan semua uji asumsi klasik telah terpenuhi dan tidak ada pelanggaran, maka data layak dianalisis menggunakan analisis regresi linier berganda.

\subsection{Analisis Regresi Linier Berganda}

Perhitungan statistik dalam analisis regresi linier berganda yang digunakan dalam penelitian ini adalah dengan menggunakan bantuan program komputer SPSS for WindowS versi 23.0. Hasil pengolahan data dengan menggunakan program SPSS selengkapnya ada pada lampiran dan selanjutnya diringkas sebagai berikut :

Tabel 8

Coefficients $^{\mathrm{a}}$

\begin{tabular}{|c|c|c|c|c|c|c|}
\hline \multirow{2}{*}{\multicolumn{2}{|c|}{ Model }} & \multicolumn{2}{|c|}{ Unstandardized Coefficients } & \multirow{2}{*}{$\begin{array}{c}\begin{array}{c}\text { Standardized } \\
\text { Coefficients }\end{array} \\
\text { Beta }\end{array}$} & \multirow[b]{2}{*}{ T } & \multirow[b]{2}{*}{ Sig. } \\
\hline & & $\mathrm{B}$ & Std. Error & & & \\
\hline 1 & (Constant) & 17.257 & 6.971 & & .476 & .020 \\
\hline & $\mathrm{X} 1$ & .428 & .327 & .651 & 2.808 & .003 \\
\hline & $\mathrm{X} 2$ & .530 & .318 & .415 & 2.967 & .015 \\
\hline & $\mathrm{X} 3$ & .599 & .229 & .641 & 4.179 & .000 \\
\hline & $\mathrm{X} 4$ & .428 & .506 & .470 & 2.845 & .008 \\
\hline & $\times 5$ & .605 & .598 & .724 & 2.911 & .010 \\
\hline
\end{tabular}

Hasil Analisis Regresi Linier Berganda

Dari tabel output di atas, diketahui bahwa nilai a yang di peroleh adalah sebesar 17,257 nilai $\beta 1=0,428, \beta 2=0,530, \beta 3=0,599, \beta 4=0,428, \beta 5=0,605$, sehingga dapat di bentuk persamaan regresi linier berganda sebagai berikut :

$Y=17,257+0,428 X_{1}+0,530 X_{2}+0,499 X_{3}+0,428 X_{4}+0,605 X_{5}+e$

Persamaan di atas dapat diartikan sebagai berikut :

1. $a=17,257$ artinya jika variabel lingkungan pengendalian (X1), penilaian risiko (X2), kegiatan pengendalian (X3), informasi dan komunikasi (X4), dan pemantauan (X5) bernilai nol (0) maka variabel kualitas laporan keuangan $(\mathrm{Y})$ akan bernilai 17,257.

2. 0,428 , artinya jika variabel lingkungan pengendalian (X1) meningkat sebanyak satu satuan, maka variabel kualitas laporan keuangan $(Y)$ akan meningkat sebesar 0,428.

3. 0,530 , artinya jika variabel penilaian resiko (X2) meningkat sebanyak satu satuan, maka variabel kualitas laporan keuangan $(Y)$ akan meningkat sebesar 0,530.

4. 0,499 , artinya jika variabel kegiatan pengendalian (X3) meningkat sebanyak satu satuan, maka variabel kualitas laporan keuangan $(Y)$ akan meningkat sebesar 0,499.

5. 0,428 , artinya jika variabel informasi dan komunikasi (X4) meningkat sebanyak satu satuan, maka variabel kualitas laporan keuangan $(\mathrm{Y})$ akan meningkat sebesar 0,428. 
6. 0,605 , artinya jika variabel pemantauan (X5) meningkat sebanyak satu satuan, maka variabel kualitas laporan keuangan (Y) akan meningkat sebesar 0,605.

\section{Pengujian Hipotesis \\ Uji Koefisien Determinasi (R2)}

Nilai R2 yang semakin mendekati 1, berarti variabel-variabel independen memberikan hampir semua informasi yang dibutuhkan untuk memprediksi variabel independen. Koefisien determinasi yang digunakan adalah nilai Adjusted $\mathrm{R}$ square karena lebih dapat dipercaya dalam mengevaluasi model regresi. Nilai Adjusted $R$ square dapat naik atau turun apabila satu variabel independen ditambahkan ke dalam model :

Tabel 9

Model Summary

\begin{tabular}{|l|r|r|r|r|}
\hline Model & $\mathrm{R}$ & $\mathrm{R}$ Square & Adjusted R Square & $\begin{array}{c}\text { Std. Error of the } \\
\text { Estimate }\end{array}$ \\
\hline 1 & $.789^{\mathrm{a}}$ & .622 & .411 & 2.444 \\
\hline
\end{tabular}

Hasil Pengujian Koefisien Determinasi

Dari tabel output di atas, diketahui bahwa nilai koefisien determinasi atau $R$ Square yang diperoleh adalah sebesar 0,622 atau 62,2\%. Hal ini menunjukkan bahwa secara simultan system pengendalian internal (lingkungan pengendalian (X1), penilaian risiko (X2), kegiatan pengendalian (X3), informasi dan komunikasi (X4), dan pemantauan (X5)) memberikan kontribusi pengaruh terhadap kualitas laporan keuangan sebesar $62,2 \%$, sedangkan sisanya sebesar $100 \%-62.2 \%=47,8 \%$ merupakan pengaruh variabel lain yang tidak diteliti.

\subsubsection{Uji Statistik $t$ (t-test)}

Selanjutnya untuk menyakinkan bahwa masing-masing variabel yaitu : Lingkungan Pengendalian, Penilaian Resiko, Kegiatan Pengendalian, Informasi \& Komunikasi, dan Pemantauan berpengaruh terhadap Kualitas Laporan Keuangan Daerah dilakukan pengujian secara parsial. Pengujian secara parsial dapat dilihat dari uji t, apabila nilai probabilitasnya $<0,05$, Ho ditolak yang berarti ada pengaruh yang signifikan. Hasil uji parsial dapat dilihat pada tabel berikut ini:

Tabel 4.

Hasil Pengujian Statistik T (t-test) Coefficients $^{\mathrm{a}}$

\begin{tabular}{|c|c|c|c|c|c|c|}
\hline \multicolumn{7}{|c|}{ Coetriclents $^{\mathbf{a}}$} \\
\hline \multirow{2}{*}{\multicolumn{2}{|c|}{ Model }} & \multicolumn{2}{|c|}{ Unstandardized Coefficients } & $\begin{array}{l}\text { Standardized } \\
\text { Coefficients }\end{array}$ & \multirow[b]{2}{*}{$\mathrm{T}$} & \multirow[b]{2}{*}{ Sig. } \\
\hline & & $\mathrm{B}$ & Std. Error & Beta & & \\
\hline \multirow[t]{6}{*}{1} & (Constant) & 17.257 & 6.971 & & .476 & .020 \\
\hline & $\mathrm{X} 1$ & .428 & .327 & .651 & 2.808 & .003 \\
\hline & $\mathrm{X} 2$ & .530 & .318 & .415 & 2.967 & .015 \\
\hline & X3 & .599 & .229 & .641 & 4.179 & .000 \\
\hline & $\mathrm{X} 4$ & .428 & .506 & .470 & 2.845 & .008 \\
\hline & $\mathrm{x} 5$ & .605 & .598 & .724 & 2.911 & .010 \\
\hline
\end{tabular}

Berdasarkan hasil uji parsial untuk variabel Lingkungan Pengendalian diperoleh $\mathrm{t}$ hitung $=2.808$ dengan nilai signifikansi sebesar $0,003 .<0,05$ maka Ho ditolak dan $\mathrm{Ha}$ diterima. Hal ini menunjukan bahwa secara parsial $\mathrm{H} 1$ yang menyatakan bahwa ada pengaruh Lingkungan Pengendalian terhadap Kualitas Laporan Keuangan Daerah diterima.

Berdasarkan hasil uji parsial untuk variabel Penilaian Resiko diperoleh $\mathrm{t}$ hitung $=$ 2.967 dengan nilai signifikansi sebesar 0,015. Karena probabilitas signifikan jauh lebih kecil dari 0.05 maka Ho ditolak dan Ha diterima. Hal ini menunjukan bahwa secara parsial H2 yang menyatakan bahwa ada pengaruh Penilaian Resiko terhadap kinerja Kualitas Laporan Keuangan Daerah diterima. 
Berdasarkan hasil uji parsial untuk variabel Kegiatan Pengendalian diperoleh t hitung $=4.179$ dengan nilai signifikansi sebesar 0,000. Karena probabilitas signifikan jauh lebih kecil dari 0.05 maka Ho ditolak dan Ha diterima. Hal ini menunjukan bahwa secara parsial H3 yang menyatakan bahwa ada pengaruh Kegiatan Pengendalian terhadap kinerja Kualitas Laporan Keuangan Daerah diterima.

Berdasarkan hasil uji parsial untuk variabel Informasi \& Komunikasi diperoleh t hitung $=2.845$ dengan nilai signifikansi sebesar 0,008. Karena probabilitas signifikan jauh lebih kecil dari 0.05 maka Ho ditolak dan Ha diterima. Hal ini menunjukan bahwa secara parsial H3 yang menyatakan bahwa ada pengaruh Informasi \& Komunikasi terhadap kinerja Kualitas Laporan Keuangan Daerah diterima.

Berdasarkan hasil uji parsial untuk variabel Pemantauan diperoleh t hitung $=2.845$ dengan nilai signifikansi sebesar 0,008 . Karena probabilitas signifikan jauh lebih kecil dari 0.05 maka Ho ditolak dan Ha diterima. Hal ini menunjukan bahwa secara parsial H3 yang menyatakan bahwa ada pengaruh Pemantauan terhadap kinerja Kualitas Laporan Keuangan Daerah diterima.

\subsubsection{Uji Simultan (Ftest)}

Pengujian hipotesis secara bersama-sama dilakukan dengan menggunakan Uji F. Uji F dilakukan untuk menguji hubungan signifikansi antara variabel bebas dan variabel terikat secara keseluruhan. Hasil pengujian diperoleh sebagai berikut:

Tabel 10

Hasil Pengujian Simultan (Ftest)

ANOVA $^{\mathrm{a}}$

\begin{tabular}{|ll|r|r|r|r|r|}
\hline Model & & Sum of Squares & \multicolumn{1}{|c|}{ df } & Mean Square & F & Sig. \\
\hline 1 & Regression & 2.849 & 5 & .570 & 8.343 & $.001^{\mathrm{b}}$ \\
& Residual & 11.026 & 26 & .424 & & \\
& Total & 13.875 & 31 & & & \\
\hline
\end{tabular}

a. Dependent Variable: $Y$

b. Predictors: (Constant), X5, X2, X4, X3, X1

$\mathrm{H} 0$ : $\beta 1=\beta 2=\beta 3=\beta 4=\beta 5=0$ Tidak ada pengaruh yang signifikan dari Lingkungan Pengendalian, Penilaian Resiko, Kegiatan Pengendalian, Informasi \& Komunikasi, dan Pemantauan, tidak memiliki pengaruh terhadap Kualitas Laporan Keuangan Pemerintah Daerah Kabupaten Mamasa.

$\mathrm{H} 1$ : $\beta 1=\beta 2=\beta 3=\beta 4=\beta 5>0$ Ada pengaruh yang signifikan dari Lingkungan Pengendalian, Penilaian Resiko, Kegiatan Pengendalian, Informasi \& Komunikasi, dan Pemantauan memiliki pengaruh terhadap Kualitas Laporan Keuangan Pemerintah Daerah Kabupaten Mamasa.

Hasil pengujian model regresi untuk keseluruhan variabel menunjukkan nilai $\mathrm{F}$ hitung $=8,343$ dengan signifikansi 0,001 . Dengan menggunakan batas signifikansi 0,05 , nilai signifikansi tersebut lebih kecil dari 0,05. Dengan arah koefisien positif, dengan demikian diperoleh bahwa hipotesis yang menyatakan bahwa variabel dari Lingkungan Pengendalian, Penilaian Resiko, Kegiatan Pengendalian, Informasi \& Komunikasi, dan Pemantauan secara bersama-sama memiliki pengaruh yang signifikan terhadap Kualitas Laporan Keuangan Daerah.

\section{Pembahasan}

\section{Pengaruh Lingkungan Pengendalian (X1) terhadap Kualitas Laporan Keuangan Pemerintah Daerah (Y)}

Berdasarkan hipotesis pertama menunjukkan bahwa Lingkungan Pengendalian berpengaruh terhadap Kualitas Laporan Keuangan Pemerintah Daerah yang ditunjukkan dengan hasil uji $t$ variabel Lingkungan Pengendalian sebesar 2.808 lebih besar dari t tabel sebesar 1.70562 dan nilai sig. sebesar 0.003 lebih kecil dari 0,05 (5\%), sehingga $\mathrm{H} 1$ diterima artinya Lingkungan Pengendalian berpengaruh terhadap Kualitas Laporan 
Keuangan Pemerintah Daerah secara statistik signifikan. Berdasarkan hasil ini menunjukkan adanya kesamaan penelitian yang dilakukan oleh oleh Nella (2014) bahwa lingkungan pengendalian merupakan faktor yang memiliki persentase tertinggi dalam pelaksanaan sistem pengendalian intern pemerintah. Sejalan dengan penelitian Rumondang (2010) lingkungan pengendalian merupakan kondisi dalam instansi pemerintah yang mempengaruhi efektivitas pelaksanaan sistem pengendalian intern pemerintah. Hal ini termasuk faktor-faktor seperti integritas, nilai-nilai etika, kompetensi pekerja dan filosofi manajemen dalam organisasi. Ini adalah komponen yang memberikan fondasi yang diperlukan untuk komponen lain dalam membangun sistem pengendalian keuangan internal (COSO, 2005).

Hasil penelitian ini membuktikan bahwa Kantor Dinas Pekerjaan Umum Dan Penataan Ruang Kabupaten Mamasa telah menciptakan dan memelihara lingkungan pengendalian yang menimbulkan perilaku positif dan kondusif untuk penerapan Sistem Pengendalian Intern dalam lingkungan kerjanya sesuai dengan PP No 60 tahun 2008 pasal 4.

\section{Pengaruh Penilaian Resiko (X2) terhadap Kualitas Laporan Keuangan Pemerintah Daerah (Y)}

Berdasarkan hipotesis kedua menunjukkan bahwa Penilaian Resiko berpengaruh terhadap Kualitas Laporan Keuangan Pemerintah Daerah yang ditunjukkan dengan hasil uji t variabel Penilaian Resiko sebesar 2.967 lebih besar dari t tabel sebesar 1.70562 dan nilai sig. sebesar 0.015 lebih kecil dari 0,05 (5\%), sehingga H2 diterima artinya Penilaian Resiko berpengaruh terhadap Kualitas Laporan Keuangan Pemerintah Daerah secara statistik signifikan. Hasil penelitian ini sejalan dengan penelitian oleh Widyaningsih (2015) yang menyimpulkan bahwa terdapat pengaruh penilaian risiko terhadap akuntabilitas keuangan. Menurut COSO (2004) penilaian risiko adalah komponen yang digunakan untuk mengidentifikasi risiko dalam sistem. Agar penilaian risiko menjadi efektif, langkah-langkah pencegahan diletakkan pada tempatnya dengan membentuk tujuan yang jelas. Komponen ini mengidentifikasi dan menganalisa risiko baik secara internal maupun eksternal. Komponen ini mengelola risiko dengan mengembangkan prosedur yang tepat untuk mencapai tujuan yang konsisten dalam organisasi. Penilaian risiko selalu berubah menjadi pertimbangan dalam tujuan yang ditetapkan.

Hasil penelitian ini membuktikan bahwa Kantor Dinas Pekerjaan Umum Dan Penataan Ruang Kabupaten Mamasa telah menetapkan tujuan instansi pemerintah dan tujuan pada tinkatan kegiatan dengan berpedoman pada peraturan perundang-undangan dalam hal penilaian risiko dan telah menjalankan aturan pemerintah yakni PP no 60 tahun 2008 tentang system pengendalian intern pemerintah pasal 13 dinyatakan bahwa pimpinan instansi pemerintah wajib melakukan penilaian risiko, yang terdiri atas identifikasi risiko dan analisis risiko.

\section{Pengaruh Kegiatan Pengendalian (X3) terhadap Kualitas Laporan Keuangan Pemerintah Daerah (Y)}

Berdasarkan hipotesis ketiga menunjukkan bahwa Kegiatan Pengendalian berpengaruh terhadap Kualitas Laporan Keuangan Pemerintah Daerah yang ditunjukkan dengan hasil uji t variabel Kegiatan Pengendalian sebesar 4.179 lebih besar dari t tabel sebesar 1.70562 dan nilai sig. sebesar 0.000 lebih kecil dari 0,05 (5\%), sehingga H3 diterima artinya Kegiatan Pengendalian berpengaruh terhadap Kualitas Laporan Keuangan Pemerintah Daerah secara statistik signifikan. Hasil penelitian ini sejalan dengan hasil penelitian oleh Muliati (2012) yang menunjukkan hasil bahwa kegiatan pengendalian memiliki pengaruh positif dan signifikan terhadap kualitas laporan keuangan. Penelitian oleh Martini dkk (2014) juga menyimpulkan unsur kegiatan pengendalian dapat meningkatkan kinerja. Begitu pula Widyaningsih (2015) menyimpulkan terdapat pengaruh signifikan kegiatan pengendalian terhadap akuntabilitas keuangan.

Berdasarkan hasil penelitian ini Kantor Dinas Pekerjaan Umum dan Penataan Ruang Kabupaten Mamasa membuktikan bahwa kegiatan pengendalian meliputi kebijakan, 
prosedur dan praktek yang dikembangkan untuk meningkatkan strategi manajemen risiko termasuk pemisahan tugas, verifikasi, rekonsiliasi dan keamanan fisik aset akan terus dilaksanakan. Agar efektif, aktivitas pengendalian dalam Kantor Dinas Pekerjaan Umum dan Penataan Ruang Kabupaten Mamasa harus sesuai, fungsi konsisten sesuai rencana selama periode tersebut, dan biaya yang efektif, komprehensif, masuk akal dan langsung berhubungan dengan tujuan pengendalian.

\section{Pengaruh Informasi dan Komunikasi (X4) terhadap Kualitas Laporan Keuangan Pemerintah Daerah (Y)}

Berdasarkan hipotesis keempat menunjukkan bahwa Informasi dan Komunikasi berpengaruh terhadap Kualitas Laporan Keuangan Pemerintah Daerah yang ditunjukkan dengan hasil uji t variabel Informasi dan Komunikasi sebesar 2.845 lebih besar dari t tabel sebesar 1.70562 dan nilai sig. sebesar 0.008 lebih kecil dari 0,05 (5\%), sehingga H4 diterima artinya Informasi dan Komunikasi berpengaruh terhadap Kualitas Laporan Keuangan Pemerintah Daerah secara statistik signifikan.

Hasil ini sejalan dengan hasil penelitian oleh Martini dkk (2014) di mana komponen sistem informasi dan komunikasi berpengaruh signifikan terhadap kinerja. Penelitian oleh Tahir (2015) juga menyimpulkan terdapat pengaruh positif dan signifikan informasi dan komunikasi terhadap laporan keuangan. Di mana semakin efektif informasi dan komunikasi, maka semakin baik pula laporan keuangan pemerintah. Hasil yang sejalan juga dari penelitian oleh Agustina dan Ikhsan Budi Riharjo (2016) yang menyimpulkan semakin baik alur informasi dan komunikasi dalam SKPD, maka dapat mengurangi kelemahan pengendalian intern.

Informasi dan komunikasi sangat penting dalam Kantor Dinas Pekerjaan Umum dan Penataan Ruang Kabupaten Mamasa untuk mewujudkan semua tujuan pengendalian intern. Sebuah prasyarat untuk informasi yang dapat diandalkan dan relevan adalah pencatatan yang cepat dan klasifikasi yang tepat dari transaksi dan kejadian. Informasi dalam Kantor Dinas Pekerjaan Umum dan Penataan Ruang Kabupaten Mamasa terkait telah dapat diidentifikasi, ditangkap dan dikomunikasikan dalam bentuk dan waktu yang memungkinkan staf untuk melaksanakan pengendalian internal dan tanggung jawab mereka yang lain (komunikasi yang tepat waktu kepada orang yang tepat). Oleh karena itu, sistem pengendalian internal dan seluruh transaksi dan peristiwa penting harus sepenuhnya didokumentasikan dengan cepat (INTOSAI, 1992)

\section{Pengaruh Pemantauan (X5) terhadap Kualitas Laporan Keuangan Pemerintah Daerah} (Y)

Berdasarkan hipotesis kelima menunjukkan bahwa Pemantauan berpengaruh terhadap Kualitas Laporan Keuangan Pemerintah Daerah yang ditunjukkan dengan hasil uji t variabel Pemantauan sebesar 2.911 lebih besar dari t tabel sebesar 1.70562 dan nilai sig. sebesar 0.010 lebih kecil dari 0,05 (5\%), sehingga H5 diterima artinya Pemantauan berpengaruh terhadap Kualitas Laporan Keuangan Pemerintah Daerah secara statistik signifikan. Hasil penelitian ini sejalan dengan penelitian oleh Muliati (2012) yang menunjukkan hasil bahwa pemantauan memiliki pengaruh positif terhadap kualitas laporan keuangan.

Berdasarkan hasil penelitian ini, pemantauan dalam Kantor Dinas Pekerjaan Umum dan Penataan Ruang Kabupaten Mamasa meliputi penilaian kinerja komponen pengendalian internal telah beroperasi secara efektif. Komponen ini mencakup pedoman tanggung jawab yang jelas memungkinkan manajer sehingga mereka dapat secara efektif melakukan pekerjaan mereka. Ini juga termasuk melakukan evaluasi melalui audit dan pihak independen lainnya, memastikan bahwa perusahaan sedang menangani kegiatan bisnis dengan benar (COSO,1992) dalam Effah (2011).

Sistem pengendalian internal dalam Kantor Dinas Pekerjaan Umum dan Penataan Ruang Kabupaten Mamasa harus dipantau untuk menilai kualitas kinerja sistem dari waktu ke waktu. Pemantauan dilakukan melalui kegiatan rutin, evaluasi yang terpisah atau kombinasi keduanya. Pemantauan pengendalian internal pada aktivitas kegiatan normal yang berulang 
dari suatu entitas. Ini termasuk kegiatan manajemen dan pengawasan rutin, dan tindakan personil lainnya dalam melaksanakan tugasnya. Kegiatan pemantauan meliputi pengendalian internal masing-masing komponen dan melibatkan sistem pengendalian intern terhadap tindakan yang tidak teratur, tidak etis, tidak ekonomis, tidak efisien dan tidak efektif (INTOSAI, 1992: 49).

\section{SIMPULAN}

Penelitian mengenai pengaruh Sistem Pengendalian Intern yang terdiri dari Lingkungan Pengendalian, Penilaian Resiko, Kegiatan Pengendalian, Informasi dan Komunikasi, Pemantauan terhadap Kualitas Laporan Keuangan Pemerintah Daerah dapat ditarik beberapa kesimpulan sebagai berikut :

1. Terdapat pengaruh signifikan antara Lingkungan Pengendalian, Penilaian Resiko, Kegiatan Pengendalian, Informasi dan Komunikasi, dan Pemantauan terhadap Kualitas Laporan Keuangan secara simultan;

2. Secara parsial, terdapat pengaruh signifikan antara Lingkungan Pengendalian, Penilaian Resiko, Kegiatan Pengendalian, Informasi dan Komunikasi, dan Pemantauan terhadap Kualitas Laporan Keuangan.

\section{Saran}

Organisasi Perangkat Daerah (OPD) harus meningkatkan lingkungan pengendalian dengan memperhatikan komitmen terhadap kompetensi dan memiliki prosedur yang efektif untuk memantau hasil kewenangan dan tanggung jawab yang didelegasikan. Dalam meningkatkan penilaian resiko, Instansi Pemerintah memiliki mekanisme untuk mengantisipasi, mengidentifikasi, dan bereaksi terhadap risiko yang diakibatkan oleh perubahan-perubahan dalam pemerintahan, ekonomi, industri, peraturan, operasional atau kondisi lain yang dapat mempengaruhi tercapainya maksud dan tujuan Instansi Pemerintah secara keseluruhan atau maksud dan tujuan suatu kegiatan. Organisasi Perangkat Daerah (OPD) harus meningkatkan informasi dan komunikasi dengan menggunakan berbagai bentuk komunikasi yang sesuai dengan kebutuhannya serta mengelola, mengembangkan, dan memperbaiki sistem informasinya dalam upaya meningkatkan komunikasi secara berkesinambungan.

Untuk dapat meningkatkan kualitas laporan keuangan Pemerintah daerah, pemerintah daerah harus senantiasa meningkatkan kegiatan pengendalian dengan mempertimbangkan pelimpah tugas secara sistematik ke sejumlah orang untuk memberikan keyakinan adanya checks and balances. Sebaiknya aparat pengawasan (Inspektorat Daerah) hendaknya lebih efektif dalam melakukan pembinaan seperti melakukan kontrol secara rutin pada Kantor Dinas Pekerjaan Umum Dan Penataan Ruang Kab. Mamasa.

\section{REFERENSI}

Arens, Alvin. A, Randal J.E dan Mark S.B. 2008. Auditing and Assurance Service an Integrated Approach, 11 Edition. New Jersey: Prentice-Hall.

Aristanti Widyaningsih, dkk. (2011). Hubungan Efektifitas Sistem Akuntansi Keuangan Daerah Dan Pengendalian Intern Dengan Kualitas Akuntabilitas Keuangan: Kualitas Informasi Laporan Keuangan Sebagai Variabel Intervening, dalam SNA XIV. Aceh.

Blanchard, P. Nick \& James W. Thacker. 2000. Effective Training: Systems, Strategies, and Practices. USA: Prentice-Hall, Inc

Burhan Nurgiyantoro, dkk. (2004). Statistik Terapan. Yogyakarta: Gajah Mada University Press. 
Butar Butar, Daniel. (2011). Pengaruh Kompensasi Eksekutif Dan Manajemen LabaTerhadap Risiko Kebangkrutan Pada Perusahaan Manufaktur Yang Terdaftar Di Bursa Efek Indonesia. Skripsi. Universitas Sumatera Utara.

Choirunisah, Fariziah. 2008. Faktor-Faktor yang Mempengaruhi Kualitas Informasi Laporan Keuangan yang Dihasilkan Sistem Akuntansi Instansi. Tesis. Maksi UGM, Yogyakarta.

COSO. 2013. Internal Control-Integrated Framework. Diakses dari www.coso.org pada tanggal 19 Maret 2017.

Cris Defera. (2013). Pengaruh Kelemahan Sistem Pengendalian Intern Dan Ketidakpatuhan Pada Ketentuan Perundang-UndanganTerhadap Penentuan Opini Laporan KeuanganPemerintah Daerah Di Indonesia Tahun 2008-2011.Skripsi. Yogyakarta: Universitas Atma Jaya.

Darya Setya Nugraha dan Apriyanti Susanti. (2010). The Influence of Internal Control System to The Reliability of Local Government Financial Statement (Case Study at Pemerintah Provinsi Jawa Barat). Jurnal Ekonomi, Keuangan, Perbankan, dan Akuntansi, Vol. 2 No. 2, 259-280

M. Arsyadi Ridha. (2012). Pengaruh Tekanan Eksternal, Ketidakpastian Lingkungan, Dan Komitmen Managemen Terhadap Penerapan Transparansi Pelaporan Keuangan, dalam SNA XV. Banjarmasin.

TantrianiSukmaningrum. (2012). Analisis Faktor-Faktor Yang Mempengaruhi Kualitas Informasi Laporan Keuangan Pemerintah Daerah (Studi Empiris Pada Pemerintah Kabupaten Dan Kota Semarang). Skripsi. Semarang: Universitas Diponegoro.

Wahyu Setiawan. (2012). Pengaruh Akuntabilitas Laporan Keuangan Pemerintah Daerah (LKPD)Terhadap Tingkat KorupsiPemerintah Daerah Di Indonesia. Skripsi. Semarang: Universitas Diponegoro.

Xu, et al. (2003). Key Issue Of Accounting Information Quality Management : Australian Case Studies. Industrial Management \& Data System 103/7, 461- 470. 